\title{
Posterior primary progressive prosopagnosia
}

\section{Structural and molecular imaging}

Belen Pascual, PhD, * Joseph C. Masdeu, MD, PhD, * Quentin Funk, PhD, Paolo Zanotti-Fregonara, MD, PhD, Madison Shyer, BS, Elijah Rockers, BS, and Paul E. Schulz, MD

Neurology ${ }^{\circledR}$ 2020;94:360-361. doi:10.1212/WNL.0000000000009001

Figure ${ }^{18} \mathrm{~F}-\mathrm{FDG},{ }^{18} \mathrm{~F}$-flortaucipir, and ${ }^{11} \mathrm{C}$-PBR28 PETs from a patient with amyloid-negative posterior primary progressive prosopagnosia

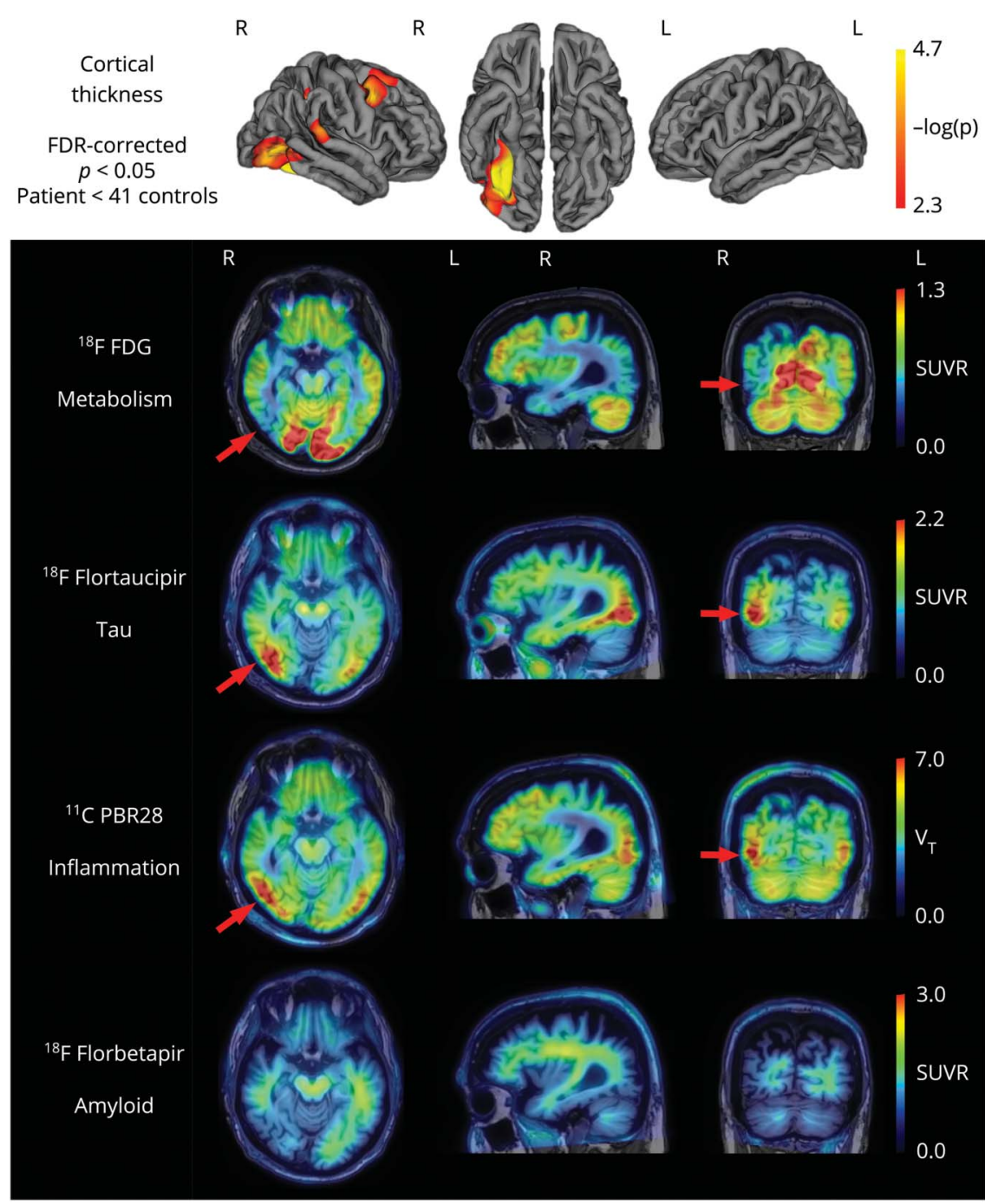

Greatest cortical thinning (top, yellow) corresponded to lowest metabolism and highest tau and inflammation uptake (arrows). standardized uptake value ratios (SUVR) were obtained by referencing to the cerebellar gray matter. ${ }^{11} \mathrm{C}$-PBR28 parametric images of total distribution volume $\left(V_{T}\right)$ were calculated using the Logan plot and a metabolitecorrected arterial input function.

\section{Correspondence}

Dr. Pascual

bpascual@

houstonmethodist.org 
Amyloid-negative pathology underlying primary progressive prosopagnosia usually affects the tip of the right temporal lobe first. ${ }^{1,2}$ However, a 69-year-old right-handed man, with amyloid-negative PET imaging, had severe progressive prosopagnosia associated with changes in the right posterior temporo-occipital cortex, including the fusiform face area, but sparing the temporal lobe tip. Brain regions affected were documented by cortical thinning on MRI and by abnormal metabolism, tau, and inflammation on PET (figure). By age 71, he had developed signs of the clinical corticobasal syndrome (CBD), as manifested by apraxia, motor impersistence, rigidity, and a supranuclear eye movement disorder. CBD was heralded by right premotor involvement in his earlier cortical thickness study (figure).

\section{Acknowledgment}

Avid Radiopharmaceuticals provided the precursor for ${ }^{18}$ flortaucipir.

\section{Study funding}

The study was funded by the Chao, Graham, Harrison, and Nantz Funds from the Houston Methodist Foundation; Avid Radiopharmaceuticals provided the ${ }^{18} \mathrm{~F}-\mathrm{AV}-1451$ precursor free of charge.

\section{Disclosure}

B. Pascual reports no disclosures relevant to the manuscript. J. Masdeu is a consultant for General Electric Healthcare and has received research support from Avid Radiopharmaceuticals. Q. Funk, P.Zanotti-Fregonara, M. Shyer, and E. Rockers report no disclosures relevant to the manuscript. P. Schulz has received research support from Avid Radiopharmaceuticals. Go to Neurology.org/ $\mathrm{N}$ for full disclosures.

\begin{tabular}{|c|c|c|c|}
\hline Name & Location & Role & Contribution \\
\hline $\begin{array}{l}\text { Belen } \\
\text { Pascual, PhD }\end{array}$ & $\begin{array}{l}\text { Houston } \\
\text { Methodist } \\
\text { Neurological } \\
\text { Institute, TX }\end{array}$ & Author & $\begin{array}{l}\text { Conceptualization of study, } \\
\text { data acquisition, data } \\
\text { analysis, drafting and } \\
\text { revising the manuscript for } \\
\text { intellectual content }\end{array}$ \\
\hline $\begin{array}{l}\text { Joseph C. } \\
\text { Masdeu, MD, } \\
\text { PhD }\end{array}$ & $\begin{array}{l}\text { Houston } \\
\text { Methodist } \\
\text { Neurological } \\
\text { Institute, TX }\end{array}$ & Author & $\begin{array}{l}\text { Conceptualization of study, } \\
\text { drafting and revising the } \\
\text { manuscript for intellectual } \\
\text { content }\end{array}$ \\
\hline $\begin{array}{l}\text { Quentin } \\
\text { Funk, PhD }\end{array}$ & $\begin{array}{l}\text { Houston } \\
\text { Methodist } \\
\text { Neurological } \\
\text { Institute, TX }\end{array}$ & Author & $\begin{array}{l}\text { Data analysis, revising the } \\
\text { manuscript for intellectual } \\
\text { content }\end{array}$ \\
\hline $\begin{array}{l}\text { Paolo } \\
\text { Zanotti- } \\
\text { Fregonara, } \\
\text { MD, PhD }\end{array}$ & $\begin{array}{l}\text { Houston } \\
\text { Methodist } \\
\text { Neurological } \\
\text { Institute, TX }\end{array}$ & Author & $\begin{array}{l}\text { Data acquisition, data } \\
\text { analysis, revising the } \\
\text { manuscript for intellectual } \\
\text { content }\end{array}$ \\
\hline $\begin{array}{l}\text { Madison } \\
\text { Shyer, BS }\end{array}$ & $\begin{array}{l}\text { Houston } \\
\text { Methodist } \\
\text { Neurological } \\
\text { Institute, TX }\end{array}$ & Author & $\begin{array}{l}\text { Data acquisition, data } \\
\text { analysis, revising the } \\
\text { manuscript for intellectual } \\
\text { content }\end{array}$ \\
\hline $\begin{array}{l}\text { Elijah } \\
\text { Rockers, BS }\end{array}$ & $\begin{array}{l}\text { Houston } \\
\text { Methodist } \\
\text { Neurological } \\
\text { Institute, TX }\end{array}$ & Author & $\begin{array}{l}\text { Data analysis, revising the } \\
\text { manuscript for intellectual } \\
\text { content }\end{array}$ \\
\hline $\begin{array}{l}\text { Paul E. } \\
\text { Schulz, MD }\end{array}$ & $\begin{array}{l}\text { McGovern } \\
\text { Medical } \\
\text { School of } \\
\text { UTHealth, TX }\end{array}$ & Author & $\begin{array}{l}\text { Data acquisition, } \\
\text { revising the manuscript } \\
\text { for intellectual content }\end{array}$ \\
\hline
\end{tabular}

\section{References}

1. Josephs KA, Whitwell JL, Knopman DS, et al. Two distinct subtypes of right temporal variant frontotemporal dementia. Neurology 2009;73:1443-1450.

2. Chan D, Anderson V, Pijnenburg Y, et al. The clinical profile of right temporal lobe atrophy. Brain 2009;132:1287-1298.

\section{Disputes \& Debates: Rapid online correspondence}

The editors encourage comments on recent articles through Disputes \& Debates:

Access an article at Neurology.org/ $N$ and click on "MAKE COMMENT" beneath the article header. Responses will be posted as rapidly as possible.

Before submitting a comment to Disputes \& Debates, remember the following:

- Disputes \& Debates is restricted to comments about articles published in Neurology within the last 8 weeks

- Read previously posted comments; redundant comments will not be posted

- Your submission must be 200 words or less and have a maximum of 5 references; the first reference must be the article on which you are commenting

- You can include a maximum of 5 authors (including yourself) 


\section{Neurology}

Posterior primary progressive prosopagnosia: Structural and molecular imaging Belen Pascual, Joseph C. Masdeu, Quentin Funk, et al.

Neurology 2020;94;360-361 Published Online before print January 21, 2020

DOI 10.1212/WNL.0000000000009001

This information is current as of January 21, 2020

Updated Information \& Services

References

Permissions \& Licensing

Reprints including high resolution figures, can be found at: http://n.neurology.org/content/94/8/360.full

This article cites 2 articles, 1 of which you can access for free at: http://n.neurology.org/content/94/8/360.full\#ref-list-1

Information about reproducing this article in parts (figures,tables) or in its entirety can be found online at:

http://www.neurology.org/about/about_the_journal\#permissions

Information about ordering reprints can be found online:

http://n.neurology.org/subscribers/advertise

Neurology ${ }^{\circledR}$ is the official journal of the American Academy of Neurology. Published continuously since 1951, it is now a weekly with 48 issues per year. Copyright @ 2020 American Academy of Neurology. All rights reserved. Print ISSN: 0028-3878. Online ISSN: 1526-632X.

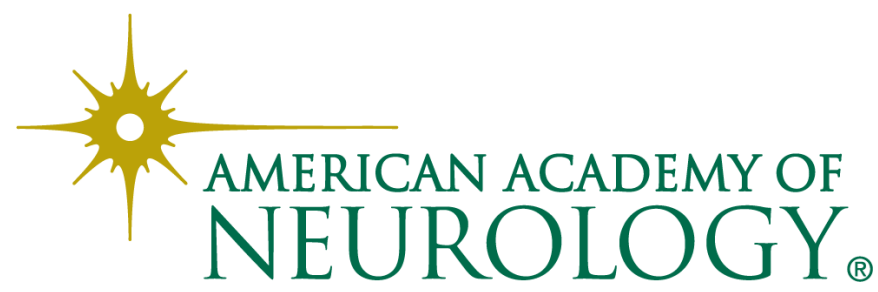

